\title{
PREBIOTICS AS FOOD SUPPLEMENTS
}

\section{PREBIOTICI KAO DODACI U ISHRANI}

Danka Đorović , Miloš Maksimović, Đorđe Radak ${ }^{2,3}$

\section{Summary}

Prebiotics are selectively fermented food ingredients that allow specific changes, both in the composition and/or activity in the gastrointestinal microflora, that confer benefits. Lactobacilli and bifidobacteria are the most common targeted genera for prebiotics. Prebiotics change the composition of the intestinal microflora, promote the growth of beneficial bacteria, improve the intestinal barrier and regulate the mucous and systemic immune response. Their intake leads to a reduction in the prevalence and duration of infectious and antibiotic-associated diarrhea. Studies have revealed the increase of calcium absorption with an increased prebiotic intake, mainly fructans. Food consumption rich in prebiotics can also affect energy intake, fat mass and changes in body weight. Literature data on the benefits of prebiotics in the prevention of cardiovascular diseases are contradictory, but some studies have shown that some prebiotics led to decrease in total- and LDL-cholesterol levels and an increase in the HDL-cholesterol concentration. Recently, many studies have examined the effect of prebiotics on CNSs functions. Due to the beneficial effects of the prebiotics, further research is needed to understand the mechanism of their positive effects on human health and general well-being. Future research should provide evidence of the efficacy, safety and dosage of prebiotics in order to be used for prevention or delaying different diseases.

Key words: prebiotics, supplementation, gut microbiota, human health, inulin

\section{Sažetak}

Prebiotici su selektivno fermentisani sastojci hrane koji dovode do specifičnih promena u sastavu i/ili aktivnosti gastrointestinalne mikroflore koje su od koristi za zdravlje domaćina. Laktobacili i bifidobakterije su najčešci sojevi bakterija na koje deluju prebiotici. Prebiotici menjaju sastav crevne mikroflore, promovišu rast korisnih bakterija, poboljšavaju intestinalnu barijeru i regulišu mukozni i sistemski imuni odgovor. Njihov unos dovodi do smanjenja prevalence i trajanja infektivne i antibioticima-izazvane dijareje. Studije su pokazale povećanu apsorpciju kalcijuma sa povećanim unosom prebiotika, uglavnom fruktana. Konzumiranje hrane bogate prebioticima može uticati i na energetski unos, masnu masu i promene u telesnoj težini. Podaci o koristi prebiotika u prevenciji kardiovaskularnih bolesti su kontradiktorni, ali neke studije su pokazale da neki prebiotici dovode do smanjenja ukupnog i LDL holesterola, kao i do povećanje koncentracije HDL holesterola. U poslednje vreme, mnoge studije ispituju uticaj prebiotika na funkcije CNS-a. Zbog korisnih efekata prebiotika, neophodna su dalja istraživanja kako bi se razumeli mehanizmi njihovog pozitivnog dejstva na ljudsko zdravlje i opšte blagostanje. Buduća istraživanja treba da obezbede dokaze o efikasnosti, bezbednosti i načinu doziranja prebiotskih proizvoda kako bi se mogli koristiti za prevenciju ili odlaganje razlicititih bolesti.

Ključne reči: prebiotici, suplementacija, crevna mikrobiota, ljudsko zdravlje, inulin

\section{INTRODUCTION}

Intestinal microbiota has been the focus of interest among scientists from different fields for the last 20 years, because there is increasing evidence of its significant impact on human health. A diverse population of microorganisms in the gastrointestinal tract, especially in the colon, has numerous protective, metabolic and structural functions that are associated with homeostasis regulation and health benefits. Gut microbiota is regulated by numerous factors such as microbilogical factors, host characteristics, nutrition pattern and environmental factors. (1) One of the ways to influence gut microbiota is consumption of non-digestible food ingredients known as prebiotics.

Prebiotics were first defined as non-digestible food ingredients that beneficially affect the host by stimulating the growth and/or activity of one or a limited number of bacteria in the colon selectively, thus improving host health. This definition was later modified to include other areas of human organism that may benefit from selective targeting of particular microorganisms. According to the new definition, prebiotics are selectively fermented food ingredients that allow specific changes, both in the composition and/or activity in the gastrointestinal microflora, that confer benefits. (2) Lactobacilli and bifidobacteria are the most common targeted genera for prebiotics. Changes in bifidobacteria are more likely, and this may be due to the fact that more bifidobacteria usually reside in the human colon than lactobacilli.

In order to be classified as prebiotics, food ingredients must fulfill the following three criteria: 1) is resistant to gastric acid, enzymatic hydrolysis and gastrointestinal absorption; 2) is fermented by the intestinal microflora; and 3) selectively stimulate the growth and/or activity of intestinal bacteria that are beneficial for health. Prebiotic selectivity is mainly related to the strains of bifidobacteria and lactobacilli, but also to some other groups of bacteria, provided that the extent of the microorganisms to which they act should be limited. 
All prebiotics described in the literature are short-chain carbohydrates with a degree of polymerization between two and sixty. Prebiotics with scientifically-proven functional properties are inulin, fructooligosaccharides (FOS) and galactooligosaccharides (GOS). Potential prebiotics are isomalto-oligosaccharides (IMO), xylo-oligosaccharides (XOS), resistant starch, and soybean oligosaccharides (SOS). (3)

Prebiotics are natural elements of human nutrition under condition that fruits and vegetables, as well as whole grain cereals, are consumed in appropriate quantities. Food rich with prebiotics include leeks, asparagus, chicory, Jerusalem artichokes, garlic, onion, wheat, oats, barley, bananas, soybean, etc. This food has been consumed since prehistoric times. Archaeological evidence from dry cave deposits in the northern Chihuahuan Desert show intensive utilization of desert plants that were high in inulin. (4) Analysis of well-preserved coprolites suggest that dietary intake of inulin was about $135 \mathrm{~g} /$ day for the typical adult male hunter-forager. The use of these natural sources of prebiotics in modern American and European nutrition is estimated at just a few grams per day, which is why more often consumed food is fortified by prebiotic and potentially prebiotic products. Inulin, FOS and GOS were tested by the US Food and Drug Administration (FDA) and were confirmed as safe. $(5,6,7)$ If added to different type of food such as yogurt, cereals, bread, biscuits, ice cream, spreads, beverages and supplements, prebiotics can be considered a sub-category of functional foods.

\section{Colonic Microflora and Fermentation}

Very important prebiotics mechanism is fermentation in the colon and changes in intestinal microflora. The colon is one of the most diversely colonized and metabolically active organs in the human body. (8) The colonic environment is favorable for bacterial growth due to its slow motility, easily available nutrients and favorable $\mathrm{pH}$. Generally speaking, the bacteria that possess a saccharolytic metabolism (without proteolytic activity) almost entirely, can be considered potentially beneficial. Such a metabolic profile is typical for lactobacilli and bifidobacteria, targeted groups of bacteria for prebiotics. Furthermore, the intestinal flora is supplied with energy through fermentation of short-chain carbohydrates not digested in the upper gut, such as prebiotics. Colonic bacteria use a range of carbohydrate hydrolyzing enzymes to produce hydrogen, methane, carbon dioxide, short-chain fatty acids (SCFAs) and lactate. These fermentation products provide further energy for colonocytes and some bacteria.

It has been displayed that fermentation, particularly the production of SCFAs (mainly acetate, propionate and butyrate), play a multiple role at both local and systemic lev- el. (9) SCFAs are water-soluble and absorbed through the blood stream. Acetate is not metabolized in the liver, but its metabolism occurs in the organs including the brain, heart and skeletal muscles. On the contrary, propionate is mainly used as a substrate for gluconeogenesis in the liver and can reduce hepatic production of cholesterol by interfering with its synthesis. Butyrate is considered a key nutrient determining the metabolic activity and growth of colonocytes and may function as a primary protective factor against colon cancer and ulcerative colitis. (10) Fermentation and SCFAs production also inhibit the growth of pathogenic microorganisms by reducing luminal $\mathrm{pH}$. Low $\mathrm{pH}$ reduces the production of toxic compounds like ammonia, amines and phenolic compounds resulting from peptide degradation. Moreover, it reduces the activity of undesirable bacterial enzymes.

\section{HeAlTh BeNEFits OF PREBIOTICS}

Many studies have shown a positive effect of prebiotics on various organ systems and human health in general. Prebiotics change the composition of the intestinal microflora, promote the growth of beneficial bacteria, improve the intestinal barrier and regulate the mucous and systemic immune response. (11) Prebiotics intake leads to a reduction in the prevalence and duration of infectious and antibiotic-associated diarrhea. The study which included 244 healthy subjects traveling to high- or medium-risk destinations for diarrhea, $10 \mathrm{~g} /$ day inulin ingested for 2 weeks before the travel and 2 weeks during the travel, have reduced the frequency of diarrhea. (12) Also, intake of a mixture of FOS and inulin has produced significant reductions in disease severity indices, reduction in pro-inflammatory immune markers and a reduction in calprotectin, an abundant neutrophil protein which is elevated both in plasma and stool in patients with inflammatory bowel disease. (13)

Studies have also revealed the increase of calcium absorption with an increased prebiotic intake, mainly fructans. A 12-month study of 100 adolescents, ingesting $8 \mathrm{~g}$ of fructans per day, proved a significant increase in calcium absorption that led to greater bone mineral density. (14) The mechanism of increased calcium absorption is very complex. Enlarged calcium absorption is due to the ability of prebiotics to increase the solubility of calcium by passing water into the colon. The amplified concentration of calcium in the colon is partly due to the hydrolysis of the calcium-phytate complex using bacterial phytase which releases calcium. (15) SCFAs production in the colon that leads to a decrease in luminal $\mathrm{pH}$, results in increased concentration of calcium ions, which is a more favorable form of calcium for passive diffusion. (16)

Food consumption rich in prebiotics can also affect energy intake, fat mass and changes in body weight. 
$(17,18)$ Literature data indicate the benefits of weight loss in over-weighted and obese patients on a diet rich in prebiotics. (19.20) However, the exact mechanism is still vague. One of the mechanisms is probably the potential role of prebiotics in stimulating intestinal endocrine cells on peptide secretion (glucagon-like peptide 1 (GLP-1) and peptide YY) that can affect food intake and energy homeostasis. $(21,22)$ Another likely mechanism by which prebiotics affect body weight regulation is the production of SCFAs that have been shown to regulate the production of adipose hormones and control inflammatory process in the adipose tissue. (23) Recently, one study including over-weight adults has revealed that wheat dextrin, at doses of $8-24 \mathrm{~g} / \mathrm{day}$, increases satiety and reduces hunger. (24)

Literature data on the benefits of prebiotics in the prevention of cardiovascular diseases are contradictory. One of the major causes of cardiovascular disease is elevated cholesterol and triglycerides. A double-blind, randomized, placebo-controlled study examined the effect of consumption of $10 \mathrm{~g} /$ day inulin/FOS on lipid modification during 6 months in 17 subjects with normal lipid status. (25) Compared to placebo, consumption of inulin/FOS mixture had no effect on plasma triglyceride concentration and lipogenesis in the liver, but led to non-significant decrease in total- and LDL-cholesterol levels and an increase in the HDL-cholesterol concentration. As oligosaccharides are not viscose fibers, it is unlikely that they will reduce absorption of dietary cholesterol. Alternative mechanisms such as increased production of SCFAs, propionate in particular, are more likely mechanism by which oligosaccharides alter lipid metabolism.
The central nervous system (CNS) and intestines, including the intestinal microflora, interact with each other through continuous bidirectional communication. Many studies have examined the effect of prebiotics on CNSs functions. In one cohort study that involved 45 healthy male and female subjects, Schmidt et al. examined the effect of fructooligosaccharides (FOS) and Bimuno galactooligosaccharides (B-GOS), and showed that only B-GOSs lead to a reduction in waking cortisol response. (26) The excessive waking cortisol response is the biomarker of emotional disorders such as depression. (27) In addition, respondents also have the ability to measure vigilance or attention to negative stimuli, which are also behavioral markers of anxiety and depression. The results of this study show that B-GOS have led to a decrease in vigilance, which indicates a reduction in anxiety and depression. (28)

\section{Conclusion}

Prebiotics exhibit a diverse range of physiochemical properties and corresponding physiological effects. Based on their positive effects on human health, it is important to consume food rich in prebiotics daily. Further research is needed to understand the mechanism of their positive effect on health and general well-being. Future research should provide evidence of the efficacy, safety and dosage of prebiotics in order to be used for prevention or delaying different diseases.

\section{Founding sources}

This work was supported by Ministry of Education, Science and Technological Development, Republic of Serbia, through contract no. III41002.

\section{References}

1. Gibson GR, Probert HM, van Loo J, Rastall RA, Roberfroid MB. Dietary modulation of the human colonic microbiota: Updating the concept of prebiotics. Nutr Res Rev. 2004; 17:259-275.

2. Gibson GR, Hutkins RW, Sanders ME, Prescott SL, Reimer RA, Salminen SJ, et al. Expert consensus document: The International Scientific Association for Probiotics and Prebiotics (ISAPP) consensus statement on the definition and scope of prebiotics. Nat Rev Gastroenterol Hepatol. 2017; 14(8):491-502.

3. A. Ouwehand. Success in Applying Pro- and Prebiotics in Dairy Products. Fourth international FFNet Meeting on Functional Foods-Conference Proceedings. 2001 March 26-27; Budapest, Hungary.

4. Leach JD, Sobolik KD. High dietary intake of prebiotic inulin-type fructans in the prehistoric Chihauhuan desert. Br J Nutr. 2010; 103:1158-1561.

5. Imperial-Sensus LLC. Generally recognized as safe (gras) notification for Frutafit. GRN 118 inulin. Sugarland, TX: Imperial-Sensus LLC; 2002 Nov 14. Report No.: GRN No. 118. 61.

6. GTC Nutrition Company. Generally recognized as safe notification for short-chain fructooligosaccharide. GRN 44. Golden (CO): GTC Nutrition Company; 2000 Apr 17. Report No.: GRN No. 44. 62.

7. GTC Nutrition Company. Generally recognized as safe notification for galacto-oligosaccharide. GRN 285. Golden (CO): GTC Nutrition Company; 2009 Mar 12. Report No.: GRAS GRN 285.

8. Gibson GR, Scott KP, Rastall RA, Tuohy KM, Hotchkiss A, Dubert-Ferrandon A, et al. Dietary prebiotics: Current status and new definition. Food Sci Technol Bull Funct Foods. 2010; 7:1-19.
9. Flint HJ, Duncan SH, Scott KP, Louis P. Interactions and competition within the microbial community of the human colon: links between diet and health. Environ Microbiol. 2007; 9:1101-11.

10. Barcenilla A, Pryde SE, Martin JC, Duncan SH, Stewart CS, Henderson C, Flint HJ. Phylogenetic relationships of butyrate producing bacteria from the human gut. Appl Environ Microbiol. 2000; 66:1654-61.

11. Looijer-van Langen MA, Dieleman LA. Prebiotics in chronic intestinal inflammation, Inflammatory Bowel Dis. 2009; 15:454-462.

12. Cummings JH, Christie S, Cole TJ. A study of fructo oligosaccharides in the prevention of travellers'diarrhoea. Aliment Pharmacol Ther. 2001; 15:1139-1145.

13. Konikoff MR, Denson LA. Role of fecal calprotectin as a biomarker of intestinal inflammation in inflammatory bowel disease. Inflamm Bowel Dis. 2006; 12:524-534.

14. Abrams SA, Griffin IJ, Hawthorne KM, Liang L, Gunn SK, Darlington G, Ellis KJ. A combination of prebiotic short- and long-chain inulin-type fructans enhances calcium absorption and bone mineralization in young adolescents. Am J Clin Nutr. 2005; 82:471-476.

15. Lopez HW, Coudray C, Levrat-Verny MA, Feillet-Coudray C, Demigné C, Rémésy C. Fructooligosaccharides enhance mineral apparent absorption and counteract the deleterious effects of phytic acid on mineral homeostasis in rats. J Nutr Biochem. 2000; 11:500-508.

16. Pérez-Conesa D, López G, Ros G. Effects of probiotic, prebiotic and synbiotic follow-up infant formulas on large intestine morphology and bone mineralisation in rats. J Sci Food Agric. 2007; 87:1059-1068. 
17. Roberfroid M, Gibson GR, Hoyles L, McCartney AL, Rastall R, Rowland I, et al. Prebiotic effects: metabolic and health benefits. Br J Nutr. 2010; 104:S1-S63.

18. Archer BJ, Johnson SK, Devereux HM, Baxter AL. Effect of fat replacement by inulin or lupin-kernel fibre on sausage patty acceptability, post-meal perceptions of satiety and food intake in men. Br J Nutr. 2004; 91:591-599.

19. Abrams SA, Griffin IJ, Hawthorne KM, Ellis KJ. Effect of prebiotic supplementation and calcium intake on body mass index. J Pediatr. 2007; 151:293-298.

20. Whelan K, Efthymiou L, Judd PA, Preedy VR, Taylor MA. Appetite during consumption of enteral formula as a sole source of nutrition: the effect of supplementing pea-fibre and fructo-oligosaccharides. $\mathrm{Br}$ J Nutr. 2006; 96:350-356.

21. Chaudhri OB, Salem V, Murphy KG, Bloom SR. Gastrointestinal satiety signals. Annu Rev Physiol. 2008; 70:239-255.

22. Cani PD, Dewever C, Delzenne NM. Inulin-type fructans modulate gastrointestinal peptides involved in appetite regulation (glucagon-like peptide-1 and ghrelin) in rats. Br J Nutr. 2004; 92:521-526.
23. Conterno L, Fava F, Viola R, Tuohy KM. Obesity and gut microbiota: does up-regulating colonic fermentation protect against obesity and metabolic disease? Genes Nutr. 2011; 6: 241-260.

24. Guerin-Deremaux L, Li S, Pochat M, Wils D, Mubasher M, Reifer C, Miller LE. Effects of NUTRIOSE ${ }^{\circledast}$ dietary fiber supplementation on body weight, body composition, energy intake, and hunger in overweight men. Int J Food Sci Nutr. 2011; 62: 628-635.

25. Forcheron F, Beylot M. Long-term administration of inulin-type fructans has no significant lipid-lowering effect in normolipidemic humans. Metabolism. 2007; 56: 1093-1098.

26. Schmidt K, Cowen PJ, Harmer CJ, Tzortzis G, Errington S, Burnet PW. Prebiotic intake reduces the waking cortisol response and alters emotional bias in healthy volunteers. Psychopharmacology.2015; 232:1793-1801

27. Mannie ZN, Harmer CJ, Cowen PJ. Increased waking salivary cortisol levels in young people at familial risk of depression. Am J Psychiatry. 2007; 164:617-621.

28. Ironside M, O'Shea J, Cowen PJ, Harmer CJ. Frontal cortex stimulation reduces vigilance to threat: Implications for the treatment of depression and anxiety. Biol Psychiatry.2016; 79:823-830. 